\title{
The Role of R\&D Investment in Firm Valuation for Small and Medium Korean Companies
}

\author{
Gee-Jung, Kwon ${ }^{1}$ \\ ${ }^{1}$ Department of Business Administration and Accounting, Hanbat National University, Republic of Korea \\ Correspondence: Gee-Jung, Kwon, Department of Business Administration and Accounting, Hanbat National \\ University, 125 Dongseodaero, Yuseong-Gu, Daejeon 305-719, Republic of Korea. Tel: 82-42-821-1337. E-mail: \\ geejung@hanmail.net
}

Received: May 29, 2014 Accepted: June 20, 2014 Online Published: July 11, 2014

doi:10.5539/ass.v10n15p169

URL: http://dx.doi.org/10.5539/ass.v10n15p169

\begin{abstract}
As technology innovation gains attention as a key value-relevant factor, many researchers raise questions about the conventional assumption that the market value of equity is a linear function of technology innovation. This study takes the view that R\&D, as a proxy for technology innovation, helps promote firm value in ways dependent on firms' characteristics and market structure. To explore this argument, this study collects data from small and medium companies listed on the Korean stock markets covering from 2001 to 2011. The results show that R\&D contributes to the promotion of the market value of equity, which, as a proxy for firm value, is in turn found to be nonlinearly associated with R\&D according to a firm's characteristics and market structure. This paper indicates the need to employ a nonlinear value relevance model in assessing the market value of equity as a function of the R\&D investments of small and medium Korean companies.
\end{abstract}

Keywords: technology innovation, $R \& D$ investment, value relevance, nonlinear value relevance, small and medium Korean company

\section{Introduction}

Much of the accounting and finance literature has reported the positive value relevance of technology innovation. Though some papers report adverse results (Coombs \& Bierly, 2006; Wolf, 2007), most research provides conclusive evidence that R\&D investment, as a proxy for technology innovation, contributes significantly to firm value (Griliches \& Mairesse, 1984; Hirschey, 1982; Hirschey \& Weygandt, 1985; Bublitz \& Entredge, 1989; Chauvin \& Hirschey, 1993; Sougiannis, 1994; Lev \& Sougiannis, 1996; Kothari, Laguerre \& Leone, 2002; Lee \& O'Neill, 2003). As technology innovation gains prominence as a key determinant of firm value, some countries, including the Republic of Korea, have changed their R\&D accounting standards and practices from expensing to capitalizing.

Most studies on R\&D as a proxy for technology innovation assume a linear relationship between the market value of equity and R\&D investment. However, as technology innovation gains attention as a key value-relevant factor, researchers are increasingly questioning the conventional assumption that the market value of equity is a linear function of technology innovation.

Likewise, empirical economics studies on technology innovation report that R\&D promotes firm value through cost-down and productivity increases (Schumpeter, 1942). However, they reject the assumption that R\&D is linearly associated with firm value. On the contrary, they show that technology innovation's nonlinear relationship to firm value depends on firm size and market structure (Scherer, 1965; Comanor \& Scherer, 1969; Rosenberg, 1976; Kang, 1994; Shin, 1999; Vossen, 1999; Mahmood \& Lee, 2004; Aghion, 2005).

In Korea, many studies have investigated whether $R \& D$ is significantly associated with firm value (Chung and Choi 2004; Ahn and Kwon 2006; Kwon, 2008; 2009a; 2009b; 2010). Most studies provide empirical evidence that $R \& D$ has a positive impact on the market value of equity. Korean studies on the value relevance of R\&D follow assumptions about the market value of equity similar to those in research performed in the U.S. and Europe, with empirical analyses that use the linear function of R\&D to assess firm value. Some studies question this linear assumption and investigate whether a nonlinear relationship between $R \& D$ and the market value of equity exists (Kang, 1994; Shin, 1999); for example Shin (1999) argues that R\&D is an inverted U-shape 
function of a firm's size. Through these studies, much of the Korean research has started to recognize that a nonlinear relationship may exist between the market value of equity and R\&D. However, studies on the nonlinear value relevance of R\&D usually focus on big companies listed on the Korean stock markets. Since $\mathrm{R} \& \mathrm{D}$ investment in big companies is much higher than in small and medium companies, most studies usually exclude the latter from their R\&D value relevance research.

The Korea Institute of Science \& Technology Evaluation and Planning (KISTEP) 2012-13 Issue Paper claims that the R\&D investment of big companies amounted to US $\$ 20,945,415,225(1 \$=1,156$ won) in 2010 , representing a $73.8 \%$ share of R\&D investment in the Korean private sector. Moreover, the top 10 companies in R\&D investment garnered a 40.2\% R\&D investment share. Even though Korean small and medium companies had a $95.3 \%(15,189)$ share in the 2010 overall number of Korean companies, they had only a $26.2 \%$ (US\$ 6,929,844,291) share in the Korean private sector's R\&D investment.

Although the amounts of R\&D investments in small and medium companies are comparatively small, such companies are more numerous than are big companies on the Korean stock markets, and thus only the value relevance of their R\&D need be investigated. Researching every company on the Korean stock markets would provide biased empirical results because of the effect of the big firms' data. In Korea, big companies usually lead in every investment area, including technology innovation, making it difficult to restrict observations to small and medium companies. Providing precise empirical results on R\&D value relevance in small and medium Korean companies allows us to identify the contributions of technology innovation to firm value and thus provides insight into ways of promoting technology innovation in such companies.

This paper investigates the nonlinear value relevance of $R \& D$ as a substitute for technology innovation in small and medium Korean companies over the period covering 2001 to 2011. This paper adopts the Ohson (1995) valuation model, replicates the empirical analysis in Morck et al. (1988), and carries out piecewise linear regressions to examine the nonlinear value relevance of R\&D. In performing the piecewise linear regression, this paper divides its sample data into two or three pieces according to the size of assets, sales, net income, book value of equity, and R\&D intensity in order to offer evidence about the changes of value relevance function in small and medium Korean companies.

The empirical results show that R\&D has a nonlinear value relevance according to the size of assets, sales, net income, book value of equity, and R\&D intensity. This result implies that R\&D increases a firm's value, that excessive R\&D may decrease the market value of equity, and that reaching a certain level of assets, sales, net income, book value of equity, and intensity allows R\&D to enhance its promotion of the market value of equity. These results offer new insights into the value-relevance shape of technology innovation and shows that a new valuation model is necessary for the evaluation of small and medium Korean companies.

This study is organized as follows. Section 2 reviews the literature on the value relevance of technology innovation in both accounting and economics. Section 3 explains the study's hypotheses and designs the empirical models used in this paper. Section 4 performs an empirical analysis to test the hypotheses using sample data on small and medium Korean companies. Finally, section 5 concludes this study and suggests future research directions.

\section{Literature Review}

\subsection{Literature on the Value Relevance of $R \& D$ Investment}

Much of the accounting, finance, and economics literature has investigated the impact of technology innovation on the market value of equity (Scherer, 1965; Rosenberg, 1976; Kaimen \& Schwartz, 1982; Griliches \& Mairesse, 1984; Hirschey, 1982; Hirschey \& Weygandt, 1985; Bublitz \& Entredge, 1989; Chauvin \& Hirschey, 1993; Cohen \& Klepper, 1994; Kang, 1994; Sougiannis, 1994; Lev \& Sougiannis, 1996; Shin, 1999; Vossen, 1999; Kothari, Laguerre \& Leone, 2002; Lee \& O'Neill, 2003; Mahmood \& Lee, 2004; Aghion, 2005; Coombs $\&$ Bierly, 2006; Wolf, 2007). Schumpeter (1942) defines technology innovation as the core driver in promoting a firm's value. Many later papers have shown that technology innovation is significantly associated with the market value of equity and have indicated that R\&D can create technology innovation in ways influenced by a firm's size and market competition (Scherer, 1965; Rosenberg, 1976; Kaimen \& Schwartz, 1982; Cohen \& Klepper, 1994; Kang, 1994; Shin, 1999; Vossen, 1999; Mahmood \& Lee, 2004; Aghion, 2005).

For example, Scherer (1965) finds that the size of a company is significantly associated with the number of its patents, which proxy for technology innovation. Scherer (1967) also reveals that technology innovation is nonlinearly associated (in an inverted U-shape) with a firm's size and market concentration ratio. Mahmood and 
Lee (2004) also suggest that market entry barriers are significantly related to R\&D; they further document the relationship between market entry barriers and R\&D, which is also nonlinear (like the inverted U-shape).

The Korean research has investigated the empirical relationship between technology innovation and firm value. For example, Kang (1994) provides evidence on the relationship between technology innovation, market structure, and firm size, revealing that R\&D intensity, as a proxy for technology innovation, is nonlinearly associated with market concentration ratio and that the number of workers, as a proxy for firm size, is an inverted U-shape. Shin (1999) similarly reports that the number of new products, product improvements, and process improvements in manufacturing, as a proxy for technology innovation, has an inverted U-shape relationship with firm size. Yoon and Kwon (2002) show that R\&D intensity, representing technology innovation, has a U-shaped relationship with the market value of equity in Korean IT companies. Contrariwise, Park (2010) concludes that Schumpeter's hypothesis is not supported in Korean stock markets by showing empirically that technology innovation does not have an inverted U-shaped relationship with market concentration ratio and firm size.

On the other hand, Griliches and Mairesse (1984), Hirschey and Weygandt (1985), Bublitz and Ettredge (1989), and Chauvin and Hirschey (1993) suggest that R\&D investment has a long-term influence on firm value. They argue that R\&D expenditure should be capitalized because it has the same characteristics as do assets that are expected to create and promote firm value over the long term. Likewise, Sougiannis (1994), Lev and Sougiannis (1996), and Hall (1999) argue that R\&D should be treated as an intangible asset because it can influence a firm's value not only in the current year but also in the future.

Much of the Korean research reports empirical results similar to those of studies on R\&D capitalization. For example, Cho (1998) finds that R\&D influences a firm's profitability for four years, and Cho and Jung (2001) find that R\&D investment has a long-term impact on a firm's value for two to four years. In addition, Cho and Jung (2001), Chung and Choi (2004), and Ahn and Kwon (2006) show that R\&D investment is significantly associated with the market value of equity not only for the current year but also for the foreseeable future. However, these studies assume that a linear relationship exists only between R\&D investment and the market value of equity, without considering firm size, market structure, and market competition.

Moreover, although most studies agree that technology innovation is a key value-relevant factor, the way technology innovation influences the market value of equity is still a matter of dispute. Furthermore, most studies on the value relevance of $R \& D$ have paid little attention to small and medium companies

\subsection{An Overview of R\&D Investment in Small and Medium Korean Companies}

In 2002, the OECD defines $R \& D$ as a creative activity derived from technology innovation that innovates the manufacturing process and eventually connects to the promotion of firm value. According to KISTEP's 2011 Survey of Research and Development in Korea, total Korean R\&D investment amounted to 43,840,421,793 dollars (US\$ $1=1,138$ won at the end of 2011), representing a 4.03\% share of total Korean GDP. The survey also reported that Korea's total R\&D investment ranked sixth worldwide.

Korea's big companies take the lead in R\&D investment. According to KISTEP (2012), the R\&D investment of Korea's big companies amounted to 20,945,415,225 dollars (US\$ $1=1,156$ won at the end of 2010), for a $73.8 \%$ share of the R\&D investment. The top 10 firms in $R \& D$ investment took an overall $40.2 \%$ share in the private sector. Although small and medium companies represented 95.3\% $(15,189)$ of all Korean companies in 2010, they had only a $26.2 \%$ share in Korea's private sector R\&D investment, which totaled 6,929,844,291 dollars. .

Though the R\&D investment of Korea's small and medium companies is smaller than that of big firms, the former outnumber the latter on Korean stock markets. It is thus necessary to extend the scale of small and medium companies' R\&D investment. It is also necessary to examine how R\&D influences small and medium companies' value and suggest policies for the R\&D activities of such firms.

\section{Hypothesis and Empirical Model}

\subsection{Hypothesis}

Schumpeter $(1942 ; 1947)$ and Scherer $(1965 ; 1967)$ conclude that technology innovation is nonlinearly associated with firm size because big companies benefit more from economies of scale than do small ones. Similarly, Chauvin and Hirschey (1993) and Jung and Lee (1996) also show that technology innovation provides more benefits to big firms than to small ones.

On the contrary, Kaimen and Schwartz (1982), Cohen and Klepper (1994), Acs and Audretsch (1987), Hausman, Hall, and Griliches(1984), and Kim and Marschke (2004) conclude that technology innovation in big firms has 
more disadvantages than in small firms and that R\&D is therefore negatively associated with firm size. Thus, the empirical results on the relationship between firm size and technology innovation are still inconsistent. It is therefore necessary to examine how technology innovation is associated with firm value in its association with firm size. Accordingly, this paper develops the following hypotheses. As the literature's empirical results have been inconclusive, this paper uses size variables such as assets, sales, and equity in order to ensure that its empirical results are more robust than those of previous studies.

Hypothesis 1: Technology innovation has a nonlinear relationship with the market value of equity as it relates to firm size in small and medium Korean companies

The theory of capital structure states that equity is more effective than is liability in R\&D investment financing. If this theory were correct, $R \& D$ investment would create more value in firms with a low debt ratio than in firms with a high debt ratio; if creditors were monitoring a firm's R\&D investment, on the other hand, the results of R\&D would produce more benefits for firms with high debt (Jensen, 1986; James, 1987; Zantout, 1997). According to McConnell and Servaes (1995), debt has a monitoring and disciplining effect on firms with either a low growth ratio or a high growth ratio. In addition, Ho et al. (2006) investigate whether a firm's ability to derive growth opportunities from technology innovation depends mainly on a firm's size, debt ratio, or industry concentration. They suggest that big companies' advantages over small companies disappear as their debt ratio increases, while small firms with a high debt ratio enjoy the best growth opportunities. To examine this argument, this paper proposes the second hypothesis below:

Hypothesis 2: Technology innovation has a nonlinear relationship with the market value of equity as it relates to the debt ratio of small and medium Korean companies

Levin (1978), Chan et al. (1990), and Mahmood and Lee (2004) report that industry entry barriers such as technology innovation are associated with R\&D investment. This research substitutes technology innovation for R\&D intensity, measured as the total R\&D investment divided by total sales. For example, Levin (1978) reveals that R\&D intensity can be a barrier preventing other companies from entering some industries. Chan et al. (1990) also report that the value relevance of technology innovation differs according to R\&D intensity. Mahmood and Lee (2004) similarly report that R\&D intensity, as a proxy for market competition, is significantly associated with a firm's value. Lee (2005) also reports that the market concentration ratio has negative or inverted U-shape relationship with $\mathrm{R} \& \mathrm{D}$ intensity. He suggests that high levels of market concentration decrease the power of technology innovation as a driver. This study examines that argument to test the following hypothesis:

Hypothesis 3: Technology innovation has a nonlinear relationship with the market value of equity as it relates to R\&D intensity in small and medium Korean companies

\subsection{Empirical Model}

This study uses four models to test hypotheses 1, 2, and 3. This study tests whether R\&D investment has nonlinear value relevance by using the Ohlson (1995) model, which adds an R\&D variable to an error term (see equation 1). The second model tests the nonlinear value relevance of R\&D investment proxies for technology innovation by adding square estimates of R\&D investment to model 1 (see equation 2). The third and fourth are piecewise linear regression models that test the nonlinear value relevance of R\&D according to firm size, debt ratio, and R\&D intensity (equations 3 and 4):

$$
\begin{gathered}
M V_{i, t}=a_{0}+a_{1} B V_{i, t-1}+a_{2} N I_{i, t}+a_{3} R N D_{i, t}+\varepsilon_{i, t}, \\
M V_{i, t}=a_{0}+a_{1} B V_{i, t-1}+a_{2} N I A_{i, t}+a_{3} R N D_{i, t}+a_{4} R N D_{i, t}^{2}+\varepsilon_{i, t} \\
M V_{i, t}=a_{0}+a_{1} B V_{i, t-1}+a_{2} N I_{i, t}+a_{3} R N D_{i, t}+a_{4} R N D_{i, t} * D+a_{5} D+\varepsilon_{i, t} \\
M V_{i, t}=a_{0}+a_{1} B V_{i, t-1}+a_{2} N I_{i, t}+a_{3} R N D_{i, t}+a_{4} R N D_{i, t} * D_{M} a_{4}+a_{5} R N D_{i, t} * D_{H}+a_{6} D_{M}+a_{7} D_{H^{\prime}}+\varepsilon_{i, t}
\end{gathered}
$$

where $M V_{i, t}=$ stock price at the end of fiscal year t, $B V_{i, t-1}=$ book value of equity at the end of year t-1 deflated by total number of shares outstanding in year $\mathrm{t}, N I_{i, t}=$ accounting earnings in period teflated by total number of shares outstanding in year $\mathrm{t}$, and $R N D_{i, t}=$ total $\mathrm{R} \& \mathrm{D}$ investment (sum of expensed R\&D and capitalized R\&D) in period $\mathrm{t}$ deflated by total number of shares outstanding in year $\mathrm{t}$.

In equation $2, R N D_{i, t}^{2}=$ the square estimates of $R N D_{i, t}$. In equation (3), $\mathrm{D}=$ dummy variable, if assets, sales, debt ratio, and $R \& D$ intensity are bigger than break point $D=1$, otherwise $D=0$. In equation $4, D_{M}=$ dummy variable, if assets, sales, debt ratio and $R \& D$ intensity are bigger than the first breakpoint $D_{M}=1$, otherwise $D_{M}=$ $0, \mathrm{D}_{\mathrm{H}}=$ dummy variable, if assets, sales, debt ratio, and $\mathrm{R} \& \mathrm{D}$ intensity are bigger than the second breakpoint $\mathrm{D}_{\mathrm{H}}$ $=1$, otherwise $\mathrm{D}_{\mathrm{H}}=0$. 


\section{Empirical Analysis}

\subsection{Sample Selection}

This paper's data on small and medium Korean companies, obtained from the KIS-FAS (Korea Investors Service-Financial Analysis System) LIBRARY databases, cover from 2001 to 2011 . The selection criteria were the following:

i ) Firms that do not settle their accounts at the end of December are excluded because this time difference is significant.

ii ) Firms that perform banking, legal management, or capital firm impairment are excluded because those firms' data usually show outliers and abnormal estimates.

iii) Firms without variable estimates such as stock prices, book values, accounting earnings, or R\&D investments recorded in the KIS-FAS LIBRARY database are excluded.

iv) Firms with outliers with a Cook's Distance greater than 0.5 and an absolute value of studentized residuals greater than 1 in every regression are excluded.

Table 1 shows the total numbers for the sample data.

Table 1. Selection of sample firms

\begin{tabular}{lr}
\hline Small and Medium Companies extracted from KIS-FAS DB at the end of 2001-2011 (firm-year) & 12,309 \\
\hline Minus (-): & $(4,660)$ \\
(1) Companies that do not settle their accounts in December & \\
(2) Financial banking business \\
(3) Legal management firms \\
(4) Impairment of capital firms \\
(5) Companies that do not have variable data in KIS-FAS DB
\end{tabular}

Total sample firms (firm-year)

7,649

\subsection{Empirical Analysis}

\subsubsection{Summary Statistics}

Table 2 presents the summary statistics for the variables of this study covering 2001 to 2011. All variable estimates in Table 2 are deflated by the shares outstanding in year t. The mean estimate of $M V_{i, t}$ is 5,952 , that of $B V_{i, t-1}$ is 6,403, that of $N I_{i, t}$ is 388.33 , and that of $R N D_{i, t}$ is around 124.54. The maximum estimate of $M V_{i, t}$ is 224,000 , that of $B V_{i, t-1}$ is 165,447 , that of $N I_{i, t}$ is 34,202 , and that of $R N D_{i, t}$ is 5,132 . The minimum estimate of $M V_{i, t}$ is 40.00 , that of is $B V_{i, t-1}$ is 1.11 , that of $N I_{i, t}$ is $-24,144.00$, and that of $R N D_{i, t}$ is 0.00 .

Table 2. Descriptive statistics

\begin{tabular}{|c|c|c|c|c|c|c|}
\hline year & Number & Variables & Min & Max & Mean & $\begin{array}{l}\text { Standard } \\
\text { deviation }\end{array}$ \\
\hline \multirow{4}{*}{2001} & \multirow{4}{*}{423} & $\mathrm{MV}_{\mathrm{t}}$ & 41.00 & $74,000.00$ & $5,229.15$ & $7,575.57$ \\
\hline & & $\mathrm{BV}_{\mathrm{t}-1}$ & 41.92 & $131,612.70$ & $6,082.23$ & $10,978.08$ \\
\hline & & $\mathrm{NI}_{\mathrm{t}}$ & $-9,143.39$ & $34,201.57$ & 327.80 & $2,065.19$ \\
\hline & & $\mathrm{RND}_{\mathrm{t}}$ & 0.00 & $2,481.53$ & 102.53 & 237.67 \\
\hline \multirow{4}{*}{2002} & \multirow{4}{*}{502} & $\mathrm{MV}_{\mathrm{t}}$ & 40.00 & $44,900.00$ & $3,363.78$ & $4,904.11$ \\
\hline & & $\mathrm{BV}_{\mathrm{t}-1}$ & 12.96 & $129,858.10$ & $5,879.64$ & $11,080.26$ \\
\hline & & $\mathrm{NI}_{\mathrm{t}}$ & $-6,651.01$ & $8,066.28$ & 356.28 & $1,183.45$ \\
\hline & & $\mathrm{RND}_{\mathrm{t}}$ & 0.00 & $1,678.50$ & 94.86 & 200.66 \\
\hline
\end{tabular}




\begin{tabular}{|c|c|c|c|c|c|c|}
\hline \multirow{4}{*}{2003} & \multirow{4}{*}{560} & $\mathrm{MV}_{\mathrm{t}}$ & 92.00 & $92,900.00$ & $3,523.95$ & $6,498.99$ \\
\hline & & $B V_{t-1}$ & 1.11 & $130,202.40$ & $5,677.61$ & $10,819.87$ \\
\hline & & $\mathrm{NI}_{\mathrm{t}}$ & $-9,791.89$ & $9,487.49$ & 278.56 & $1,237.20$ \\
\hline & & $\mathrm{RND}_{\mathrm{t}}$ & 0.00 & $2,547.82$ & 94.43 & 203.11 \\
\hline \multirow{4}{*}{2004} & \multirow{4}{*}{593} & $\mathrm{MV}_{\mathrm{t}}$ & 45.00 & $58,700.00$ & $3,504.24$ & $5,883.30$ \\
\hline & & $\mathrm{BV}_{\mathrm{t}-1}$ & 22.09 & $131,855.30$ & $5,928.97$ & $11,453.73$ \\
\hline & & $\mathrm{NI}_{\mathrm{t}}$ & $-24,144.20$ & $19,723.49$ & 413.59 & $1,998.11$ \\
\hline & & $\mathrm{RND}_{\mathrm{t}}$ & 0.00 & $3,124.02$ & 97.96 & 222.15 \\
\hline \multirow{4}{*}{2005} & \multirow{4}{*}{656} & $\mathrm{MV}_{\mathrm{t}}$ & 182.00 & $80,000.00$ & $6,957.18$ & $9,439.82$ \\
\hline & & $B V_{t-1}$ & 15.45 & $136,110.80$ & $5,913.18$ & $11,346.49$ \\
\hline & & $\mathrm{NI}_{\mathrm{t}}$ & $-19,978.50$ & $15,493.92$ & 337.30 & $1,667.39$ \\
\hline & & $\mathrm{RND}_{\mathrm{t}}$ & 0.00 & $2,605.18$ & 112.05 & 247.68 \\
\hline \multirow{4}{*}{2006} & \multirow{4}{*}{702} & $\mathrm{MV}_{\mathrm{t}}$ & 79.00 & $89,000.00$ & $6,174.16$ & $8,693.78$ \\
\hline & & $\mathrm{BV}_{\mathrm{t}-1}$ & 17.16 & $131,446.00$ & $6,267.30$ & $11,590.15$ \\
\hline & & $\mathrm{NI}_{\mathrm{t}}$ & $-13,664.40$ & $11,139.03$ & 357.53 & $1,404.53$ \\
\hline & & $\mathrm{RND}_{\mathrm{t}}$ & 0.00 & $4,405.66$ & 122.13 & 284.74 \\
\hline \multirow{4}{*}{2007} & \multirow{4}{*}{765} & $\mathrm{MV}_{\mathrm{t}}$ & 230.00 & $129,000.00$ & $7,662.33$ & $12,422.91$ \\
\hline & & $B V_{t-1}$ & 13.03 & $128,497.30$ & $6,181.03$ & $11,565.46$ \\
\hline & & $\mathrm{NI}_{\mathrm{t}}$ & $-7,870.61$ & $14,486.79$ & 408.16 & $1,500.06$ \\
\hline & & $\mathrm{RND}_{\mathrm{t}}$ & 0.00 & $2,699.45$ & 130.07 & 283.21 \\
\hline \multirow{4}{*}{2008} & \multirow{4}{*}{797} & $\mathrm{MV}_{\mathrm{t}}$ & 65.00 & $75,900.00$ & $4,396.43$ & $7,985.55$ \\
\hline & & $B V_{t-1}$ & 14.29 & $165,446.90$ & $6,643.62$ & $13,269.14$ \\
\hline & & $\mathrm{NI}_{\mathrm{t}}$ & $-22,802.00$ & $22,694.93$ & 188.00 & $2,274.01$ \\
\hline & & $\mathrm{RND}_{\mathrm{t}}$ & 0.00 & $3,334.08$ & 138.25 & 297.28 \\
\hline \multirow{4}{*}{2009} & \multirow{4}{*}{846} & $\mathrm{MV}_{\mathrm{t}}$ & 71.00 & $120,500.00$ & $7,088.35$ & $10,939.05$ \\
\hline & & $B V_{t-1}$ & 18.23 & $152,542.80$ & $6,623.16$ & $13,403.93$ \\
\hline & & $\mathrm{NI}_{\mathrm{t}}$ & $-12,643.80$ & $24,096.92$ & 596.82 & $2,094.48$ \\
\hline & & $\mathrm{RND}_{\mathrm{t}}$ & 0.00 & $2,961.84$ & 133.85 & 263.64 \\
\hline \multirow{4}{*}{2010} & \multirow{4}{*}{904} & $\mathrm{MV}_{\mathrm{t}}$ & 180.00 & $224,000.00$ & $7,672.97$ & $13,898.74$ \\
\hline & & $\mathrm{BV}_{\mathrm{t}-1}$ & 6.44 & $140,847.40$ & $7,074.10$ & $14,126.31$ \\
\hline & & $\mathrm{NI}_{\mathrm{t}}$ & $-18,190.30$ & $27,308.07$ & 539.79 & $2,213.29$ \\
\hline & & $\mathrm{RND}_{\mathrm{t}}$ & 0.00 & $3,630.12$ & 154.87 & 316.61 \\
\hline \multirow{4}{*}{2011} & \multirow{4}{*}{901} & $\mathrm{MV}_{\mathrm{t}}$ & 104.00 & $204,000.00$ & $7,077.49$ & $12,867.22$ \\
\hline & & $\mathrm{BV}_{\mathrm{t}-1}$ & 92.58 & $132,416.60$ & $7,163.80$ & $14,549.11$ \\
\hline & & $\mathrm{NI}_{\mathrm{t}}$ & $-17,539.50$ & $20,089.24$ & 359.99 & $1,781.06$ \\
\hline & & $\mathrm{RND}_{\mathrm{t}}$ & 0.00 & $5,132.38$ & 142.60 & 312.62 \\
\hline \multirow{4}{*}{$2001-2011$} & \multirow{4}{*}{7,649} & $\mathrm{MV}_{\mathrm{t}}$ & 40.00 & $224,000.00$ & $5,952.00$ & $10,260.00$ \\
\hline & & $B V_{t-1}$ & 1.11 & $165,447.00$ & $6,403.00$ & $12,530.00$ \\
\hline & & $\mathrm{NI}_{\mathrm{t}}$ & $-24,144.00$ & $34,202.00$ & 388.33 & $1,838.00$ \\
\hline & & $\mathrm{RND}_{\mathrm{t}}$ & 0.00 & $5,132.00$ & 124.54 & 271.85 \\
\hline
\end{tabular}

Variable definitions: $\mathrm{MV}_{\mathrm{t}}$ : stock price in the end of fiscal year $\mathrm{t}$, where year $\mathrm{t}$ is the event year; $\mathrm{BV}_{\mathrm{t}-1}$ : book value of equity at the end of year t- 1 deflated by total number of shares outstanding in year $\mathrm{t} ; \mathrm{NI}_{\mathrm{t}}$ : accounting earnings in period $t$ deflated by total number of shares outstanding in year $t ; R_{N D}$ : sum of expensed $R \& D$ and capitalized R\&D in period $t$ deflated by total number of shares outstanding in year $t$. 


\subsubsection{Correlation Analysis}

Table 3 shows a Pearson correlation analysis between the main variables of this paper. MV is positively correlated to NI, BV, and RND at the $1 \%$ level of significance. The Pearson correlation between independent variables BV, NI, and RND are $0.39442,0.20661$, and 0.14055 respectively at the $1 \%$ level of significance. Since all variance inflation factor (VIF) estimates are smaller than 2, the possibility of multicollinearity is low.

Table 3. Pearson correlations

\begin{tabular}{ccccc}
\hline Variables & MV & BV & NI & RND \\
\hline MV & 1.00000 & & & \\
BV & $0.59977^{* * *}$ & 1.00000 & & \\
NI & $0.54301^{* * *}$ & $0.39442^{* * *}$ & 1.00000 & 1.00000 \\
RND & $0.29396^{* * *}$ & $0.20661^{* * *}$ & $0.14055^{* *}$ & 1.000 \\
\hline
\end{tabular}

1) Pearson's coefficient of correlation, two-sided test, variable definitions: Refer to Table 2

2) $* \mathrm{p}<0.1, * * \mathrm{p}<0.05, * * * \mathrm{p}<0.01$

4.2.3 Regressions for the Nonlinear Value Relevance of R\&D Investment

Table 4 presents the regression results on the nonlinear value relevance of R\&D investment from 2001 to 2011 in small and medium firms listed on Korean stock markets. Model 1 is a converted Ohlson (1995) model with an $R \& D$ variable inserted into the error to test the value relevance of $R \& D$ investment. Model 2 is designed to test the nonlinear value relevance of $R \& D$ investment by adding square estimates of $R \& D$ investment into model 1 .

As shown in Table 4, the adjusted $\mathrm{R}^{2}$ of models $1(0.6740)$ and $2(0.6764)$ show similar estimates. Model 1 shows that technology innovation (RND) is significantly related to a firm's value at $1 \%$ level (4.40890). In model 1, BV (0.34852) and NI (1.64014) also show significant value relevance at the $1 \%$ level. Model 2 indicates that $\mathrm{RND}^{2}$ is negatively associated with the market value of equity at the $1 \%$ level of significance $(-0.00120)$. This result suggests that RND is nonlinearly related to firm value.

Table 4. Test for the value relevance function of R\&D investment

\begin{tabular}{|c|c|c|c|}
\hline \multicolumn{2}{|c|}{ Variables \& Expected Sign } & \multirow[t]{2}{*}{ Model 1} & \multirow[t]{2}{*}{ Model 2} \\
\hline Variables & Expected Sign & & \\
\hline Intercept & $?$ & $2938.81813 * * *$ & $2796.51327 * * *$ \\
\hline BV & + & $0.34852 * * *$ & $0.34924 * * *$ \\
\hline NI & + & $1.64014 * * *$ & $1.65250 * * *$ \\
\hline RND & + & $4.40890 * * *$ & $6.55095 * * *$ \\
\hline $\mathrm{RND}^{2}$ & - & & $-0.00120 * * *$ \\
\hline \multicolumn{2}{|c|}{$\Sigma \mathrm{YD}$} & Included & Included \\
\hline \multicolumn{2}{|c|}{$\Sigma \mathrm{IND}$} & Included & Included \\
\hline \multicolumn{2}{|c|}{ F Value } & 864.57 & 828.26 \\
\hline \multicolumn{2}{|c|}{ Adj R-Sq } & 0.6740 & 0.6764 \\
\hline \multicolumn{2}{|c|}{ Number of sample } & 7,649 & 7,649 \\
\hline
\end{tabular}
1) Variable definitions: refer to Table 2
2) Model 1: $M V_{i, t}=a_{0}+a_{1} B V_{i, t-1}+a_{2} N I_{i, t}+a_{3} R N D_{i, t}+\varepsilon_{i, t}$,
3) Model 2: $M V_{i, t}=a_{0}+a_{1} B V_{i, t-1}+a_{2} N I A_{i, t}+a_{3} R N D_{i, t}+a_{4} R N D_{i, t}^{2}+\varepsilon_{i, t}$
4) $* p<0.1, * * p<0.05, * * * p<0.01$.

4.2.4 Piecewise Linear Regression According to the Size of Asset

This study carries out a piecewise linear regression to investigate the nonlinear value relevance of $R \& D$ investment according to the size of assets in small and medium Korean companies. To do this, this study divides the sample data into two intervals according to asset size by one breakpoint, producing the First Quartile (25\%), the Second Quartile (50\%), and the Third Quartile (75\%). The paper then splits the sample data into three 
intervals by two breakpoints, producing ranges between the First Quartile (25\%) and the Second (50\%), between the Second (50\%) and the Third (75\%), and between the Second (50\%) and the Ninth Deciles $(90 \%)$.

\subsubsection{Piecewise Linear Regression According to the Size of Asset: One Breakpoint}

Table 5 shows the piecewise linear regressions used to investigate the nonlinear value relevance of R\&D investment in small and medium Korean companies between 2001 and 2011. This paper splits the sample data into two intervals according to the size of assets and carries out the piecewise linear regressions. This study sets two intervals by one breakpoint, producing the First Quartile (25\%), Second Quartile (50\%), and Third Quartile (75\%) in models 1,2 , and 3 .

Table 5 shows that the adjusted $\mathrm{R}^{2}$ of the models is 0.6764 (model 1), 0.6778 (model 2), and 0.6761 (model 3 ). Table 5 shows the coefficients of RND, RND*D, and D mean intercepts and the slopes for the lower and higher assets intervals. Coefficient $a_{0}$ represents the intercept and $a_{3}$ the slope of R\&D investment in the lower asset interval. Coefficients $a_{0}+a_{5}$ and $a_{3}+a_{4}$ stand for the intercept and the slope of R\&D investment in the higher assets interval respectively. As Table 5 indicates, the slopes of R\&D investment in the lower and higher intervals are significantly different at the $1 \%$ level of significance in every model.

In model 1, the slopes of RND are 8.62861 in the lower interval and $4.2243(8.62861+(-) 4.40431)$ in the higher interval. In model 2, the slopes of RND are 7.53934 in the lower interval and $3.61469(7.53934+(-) 3.92465)$ in the higher interval. In model 3, the slopes of RND are 4.89763 in the lower interval and 4.03976 $(4.89763+(-) 0.85787)$ in the higher interval. The coefficients of RND*D shows negative estimates at the $1 \%$ level of significance in every model, suggesting that $R \& D$ investment is nonlinearly associated with the market value of equity according to the size of assets and thus that R\&D investment becomes less value relevant as assets increase.

Table 5. Piecewise linear regression according to asset size: one breakpoint

\begin{tabular}{|c|c|c|c|c|}
\hline \multirow{2}{*}{\multicolumn{2}{|c|}{ Variables \& Expected Sign }} & \multicolumn{3}{|c|}{1 Break point } \\
\hline & & \multirow{2}{*}{$\frac{\text { Model } 1}{\text { 1st Quartile }(25 \%)}$} & \multirow{2}{*}{$\frac{\text { Model } 2}{2^{\text {nd }} \text { Quartile (50\%) }}$} & \multirow{2}{*}{$\frac{\text { Model } 3}{3^{\text {rd }} \text { Quartile (75\%) }}$} \\
\hline Variables & Expected Sign & & & \\
\hline Intercept & $?$ & $2666.75856^{* * *}$ & $2614.26227 * * *$ & $2649.18711 * * *$ \\
\hline BV & + & $0.34868 * * *$ & $0.35035 * * *$ & $0.34256^{* * *}$ \\
\hline NI & + & $1.63397 * * *$ & $1.63879 * * *$ & $1.61652 * * *$ \\
\hline RND & + & $8.62861 * * *$ & $7.53934 * * *$ & $4.89763 * * *$ \\
\hline RND*D & - & $-4.40431 * * *$ & $-3.92465 * * *$ & $-0.85787 * * *$ \\
\hline $\mathrm{D}$ & $?$ & $296.46449 * * *$ & $393.42121 * * *$ & $716.56514 * * *$ \\
\hline \multicolumn{2}{|c|}{$\Sigma Y D$} & Included & Included & Included \\
\hline \multicolumn{2}{|c|}{$\Sigma \mathrm{IND}$} & Included & Included & Included \\
\hline \multicolumn{2}{|c|}{ F Value } & 786.76 & 791.64 & 785.53 \\
\hline \multicolumn{2}{|c|}{ Adj R-Sq } & 0.6764 & 0.6778 & 0.6761 \\
\hline \multicolumn{2}{|c|}{ Number of sample } & 7,649 & 7,649 & 7,649 \\
\hline
\end{tabular}

1) Variable definitions: refer to Table 2

2) Piecewise linear regression model: $M V_{i, t}=a_{0}+a_{1} B V_{i, t-1}+a_{2} N I_{i, t}+a_{3} R N D_{i, t}+a_{4} R N D_{i, t} * D+a_{5} D+\varepsilon_{i, t}$

3) D: dummy variable, if assets are bigger than breakpoint $\mathrm{D}=1$, otherwise $\mathrm{D}=0$

4) $* p<0.1, * * p<0.05, * * * p<0.01$

4.2.4.2 Piecewise Linear Regression in Accordance with the Size of Asset: Two Breakpoints

This paper carries out a piecewise linear regression by splitting the sample firms into three intervals according to asset size. Table 6 shows the estimated coefficients of the piecewise linear approximation for nonlinear R\&D value relevance according to the three intervals of assets. This paper divides the sample firms into three intervals according to the size of their assets. Dummy variables $\mathrm{D}_{\mathrm{M}}$ and $\mathrm{D}_{\mathrm{H}}$, indicate the inflection points of the middle and high intervals according to the size of assets.

Coefficients $a_{0}$ and $a_{4}$ stand for the intercept and slope of RND in the lower assets interval, $a_{0}+a_{6}$ and $a_{4}+a_{6}$ represent the intercept and slope of RND in the middle assets interval, and $a_{0}+a_{7}$ and $a_{5}+a_{7}$ represent the intercept 
and slope of RND in the higher assets interval. As Table 6 shows, the slopes of the low, middle, and high asset intervals differ at the $1 \%$ level of significance in every model, suggesting that R\&D investment is nonlinearly related to the market value of equity.

Model 1 (see Table 6) shows that the slopes of RND are 8.70742 in the lower interval, 4.38764 $(8.70742+(-) 4.31978)$ in the middle interval, and $4.04126(8.70742+(-) 4.66616)$ in the higher interval; model 2 shows that the slopes of RND are 7.58588 in the lower interval, $3.35215(7.58588+(-) 4.23373)$ in the middle interval, and $4.03352(7.58588+(-) 3.55236)$ in the higher interval; model 3 shows that the slopes of RND are 7.58381 in the lower interval, $3.69868(7.58381+(-) 3.88513)$ in the middle interval, and 4.92374 $(7.58381+(-) 2.66007)$ in the higher interval. These results suggest that $R \& D$ is nonlinearly associated with the market value of equity according to asset size.

Table 6. Piecewise linear regression according to asset size: two breakpoints

\begin{tabular}{|c|c|c|c|c|}
\hline \multirow{2}{*}{\multicolumn{2}{|c|}{$\begin{array}{l}\text { Variables \& Expected } \\
\text { Sign }\end{array}$}} & \multicolumn{3}{|c|}{2 Break points } \\
\hline & & Model 1 & Model 2 & Model 3 \\
\hline \multirow[b]{2}{*}{ Variables } & \multirow{2}{*}{$\begin{array}{l}\text { Expected } \\
\text { Sign }\end{array}$} & $\begin{array}{l}\text { 1st break point: 1st Quartile } \\
(25 \%)\end{array}$ & $\begin{array}{c}\text { 1st break point: } 2^{\text {nd }} \text { Quartile } \\
(50 \%)\end{array}$ & $\begin{array}{c}\text { 1st break point: } 2^{\text {nd }} \text { Quartile } \\
(50 \%)\end{array}$ \\
\hline & & $\begin{array}{c}2^{\text {nd }} \text { break point: } 3^{\text {rd }} \text { Quartile } \\
(75 \%)\end{array}$ & $\begin{array}{c}2^{\text {nd }} \text { break point: } 3^{\text {rd }} \text { Quartile } \\
(75 \%)\end{array}$ & $\begin{array}{c}2^{\text {nd }} \text { break point: } 9^{\text {th }} \text { Deciles } \\
(90 \%)\end{array}$ \\
\hline Intercept & $?$ & $2523.32776^{* * *}$ & $2507.13712 * * *$ & $2499.69668 * * *$ \\
\hline BV & + & $0.34338 * * *$ & $0.34564 * * *$ & $0.34282 * * *$ \\
\hline NI & + & $1.60627 * * *$ & $1.60796^{* * *}$ & $1.59424 * * *$ \\
\hline RND & + & $8.70742 * * *$ & $7.58588 * * *$ & $7.58381 * * *$ \\
\hline $\mathrm{RND}^{*} \mathrm{D}_{\mathrm{M}}$ & - & $-4.31978 * * *$ & $-4.23373 * * *$ & $-3.88513 * * *$ \\
\hline $\mathrm{RND}^{*} \mathrm{D}_{\mathrm{H}}$ & $?$ & $-4.66616 * * *$ & $-3.55236 * * *$ & $-2.66007 * * *$ \\
\hline $\mathrm{D}_{\mathrm{M}}$ & $?$ & 107.61694 & 45.67623 & 129.84771 \\
\hline $\mathrm{D}_{\mathrm{H}}$ & $?$ & $842.07068^{* * *}$ & $803.36231 * * *$ & $1569.87763 * * *$ \\
\hline \multicolumn{2}{|c|}{$\Sigma Y D$} & Included & Included & Included \\
\hline \multicolumn{2}{|c|}{$\Sigma \mathrm{IND}$} & Included & Included & Included \\
\hline \multicolumn{2}{|c|}{ F-Value } & 721.79 & 726.95 & 733.06 \\
\hline \multicolumn{2}{|c|}{ Adj R-Sq } & 0.6784 & 0.6800 & 0.6818 \\
\hline \multicolumn{2}{|c|}{ Number of sample } & 7,649 & 7,649 & 7,649 \\
\hline
\end{tabular}

1) Variable definitions: refer to Table 2

2) Piecewise linear regression model: $M V_{i, t}=a_{0}+a_{1} B V_{i, t-1}+a_{2} N I_{i, t}+a_{3} R N D_{i, t}+a_{4} R N D_{i, t} * D_{1}+$ $a_{5} R N D_{i, t} * D_{2}+D_{1}+D_{2}+\varepsilon_{i, t}$

3) $D_{1}$ : dummy variable, if assets are bigger than first breakpoint $D=1$ and smaller than second breakpoint, otherwise $\mathrm{D}=0$

4) $D_{2}$ : dummy variable, if assets are bigger than second breakpoint $D=1$, otherwise $D=0$

5) $* p<0.1, * * p<0.05, * * * p<0.01$

Thus, tables 4,5 , and 6 show that R\&D investment, which proxies for technology innovation, has a nonlinear (i.e., inverted U-shaped) relationship with firm value as it relates to asset size.

\subsubsection{Piecewise Linear Regression According to Sales Volume}

This paper runs a piecewise linear regression to test the nonlinear value relevance of R\&D according to the sales volumes of small and medium Korean companies. The paper splits the sample companies into two intervals according to sales volume by one point of inflection, producing the First Quartile (25\%), Second Quartile (50\%), and Third Quartile (75\%) of sales. This study further divides the companies into three intervals by two points of inflection, producing ranges between the First Quartile (25\%) and the Second (50\%), the Second Quartile (50\%) and the Third (75\%), and the Second Quartile (50\%) and the Ninth Deciles (90\%) of sales. 


\subsubsection{Piecewise Linear Regression According to Sales Volume: One Breakpoint}

Table 7 presents the results of the piecewise linear regressions with the sample companies divided into two intervals, lower and higher, according to the sales volumes of small and medium Korean companies. The adjusted $\mathrm{R}^{2}$ for all models exceeds 0.6746 . The coefficients of RND, RND*D, and D stand for the intercepts and slopes for the lower and higher sales intervals. Table 7 shows that the slopes of R\&D in the lower and higher sales intervals differ significantly at the $1 \%$ level of significance in every model.

In model 1, the slopes of RND are 10.74036 in the lower interval and $3.78548(10.74036+(-) 6.95488)$ in the higher interval. In model 2, the slopes of RND are 7.26111 in the lower interval and 3.54163 $(7.26111+(-) 3.71948)$ in the higher interval. In model 3, the slopes of RND are 4.24172 in the lower interval and $4.99883(4.24172+0.75711)$ in the higher interval. The coefficients of RND*D display negative estimates in models 1 and 2, but, in model 3, the coefficient of RND*D displays a positive estimate at the $1 \%$ level of significance. This result indicates that $R \& D$ investment is nonlinearly related to the market value of equity according to sales volume.

Table 7. Piecewise linear regression according to sales volume: one breakpoint

\begin{tabular}{|c|c|c|c|c|}
\hline \multirow{2}{*}{\multicolumn{2}{|c|}{ Variables \& Expected Sign }} & \multicolumn{3}{|c|}{1 Break point } \\
\hline & & \multirow{2}{*}{$\frac{\text { Model } 1}{\text { 1st Quartile }(25 \%)}$} & \multirow{2}{*}{$\frac{\text { Model } 2}{2^{\text {nd }} \text { Quartile }(50 \%)}$} & \multirow{2}{*}{$\frac{\text { Model } 3}{3^{\text {rd }} \text { Quartile }(75 \%)}$} \\
\hline Variables & Expected Sign & & & \\
\hline Intercept & $?$ & $2746.68372 * * *$ & $2731.76283 * * *$ & $2924.54172 * * *$ \\
\hline BV & + & $0.35078^{* * *}$ & $0.34950 * * *$ & $0.34751 * * *$ \\
\hline NI & + & $1.68068 * * *$ & $1.67262 * * *$ & $1.62373 * * *$ \\
\hline RND & + & $10.74036^{* * *}$ & $7.26111 * * *$ & $4.24172 * * *$ \\
\hline $\mathrm{RND} * \mathrm{D}$ & - & $-6.95488 * * *$ & $-3.71948 * * *$ & $0.75711 * * *$ \\
\hline $\mathrm{D}$ & $?$ & 46.53852 & 117.14903 & $26.35934 * * *$ \\
\hline \multicolumn{2}{|c|}{$\Sigma Y D$} & Included & Included & Included \\
\hline \multicolumn{2}{|c|}{$\Sigma \mathrm{IND}$} & Included & Included & Included \\
\hline \multicolumn{2}{|c|}{ F Value } & 803.92 & 801.40 & 780.07 \\
\hline \multicolumn{2}{|c|}{ Adj R-Sq } & 0.6811 & 0.6805 & 0.6746 \\
\hline \multicolumn{2}{|c|}{ Number of sample } & 7,649 & 7,649 & 7,649 \\
\hline
\end{tabular}

1) Variable definitions: refer to Table 2

2) Piecewise linear regression model: $M V_{i, t}=a_{0}+a_{1} B V_{i, t-1}+a_{2} N I_{i, t}+a_{3} R N D_{i, t}+a_{4} R N D_{i, t} * D+D+\varepsilon_{i, t}$

3) $\mathrm{D}$ : dummy variable, if sales are bigger than breakpoint $\mathrm{D}=1$, otherwise $\mathrm{D}=0$

4) $* p<0.1, * * p<0.05, * * * p<0.01$

\subsubsection{Piecewise Linear Regression According to Sales Volume: Two Breakpoints}

Table 8 presents the results of the piecewise linear regressions, with the sample companies divided into three intervals, producing lower, middle, and higher sales groups according to sales volume. In Table 8, dummy variables $D_{M}$ and $D_{H}$ stand for the inflection point of the middle and higher intervals according to sales volume.

Table 8 shows that the slopes of the low, middle, and high sales intervals differ significantly at the $1 \%$ and $10 \%$ levels of significance in every model. Model 1 shows that the slopes of RND are 10.74268 in the lower interval, $3.22763(10.74268+(-) 7.51505)$ in the middle interval, and $4.92484(10.74268+(-) 5.81784)$ in the higher interval. Model 2 shows that the slopes of RND are 7.30250 in the lower interval, $1.96062(7.30250+(-) 5.34188)$ in the middle interval, and $4.98199(7.30250+(-) 2.32051)$ in the higher interval. In model 3, the slopes of RND are 7.27685 in the lower interval, $2.92535(7.27685+(-) 4.35150)$ in the middle interval, and 8.38653 $(7.27685+1.10968)$ in the higher interval. This result indicates that $R \& D$ is nonlinearly related to a firm's value as it relates to sales volume. 
Table 8. Piecewise linear regression according to sales volume: two breakpoints

\begin{tabular}{|c|c|c|c|c|}
\hline \multirow{2}{*}{\multicolumn{2}{|c|}{$\begin{array}{c}\text { Variables } \\
\text { \& Expected Sign }\end{array}$}} & \multicolumn{3}{|c|}{2 Break points } \\
\hline & & Model 1 & Model 2 & Model 3 \\
\hline \multirow[b]{2}{*}{ Variables } & \multirow{2}{*}{$\begin{array}{l}\text { Expect } \\
\text { ed Sign }\end{array}$} & $\begin{array}{c}\text { 1st break point: 1st Quartile } \\
(25 \%)\end{array}$ & $\begin{array}{c}\text { 1st break point: } 2^{\text {nd }} \text { Quartile } \\
(50 \%)\end{array}$ & $\begin{array}{l}\text { 1st break point: } 2^{\text {nd }} \\
\text { Quartile (50\%) }\end{array}$ \\
\hline & & $\begin{array}{c}2^{\text {nd }} \text { break point: } 3^{\text {rd }} \text { Quartile } \\
(75 \%)\end{array}$ & $\begin{array}{c}2^{\text {nd }} \text { break point: } 3^{\text {rd }} \text { Quartile } \\
(75 \%)\end{array}$ & $\begin{array}{l}2^{\text {nd }} \text { break point: } 9^{\text {th }} \\
\text { Deciles }(90 \%)\end{array}$ \\
\hline Intercept & $?$ & $2714.17578^{* * *}$ & $2725.74789 * * *$ & $2706.26638^{* * *}$ \\
\hline $\mathrm{BV}$ & + & $0.34995 * * *$ & $0.34521 * * *$ & $0.35166^{* * *}$ \\
\hline NI & + & $1.67339 * * *$ & $1.67195 * * *$ & $1.61343^{* * *}$ \\
\hline RND & + & $10.74268^{* * *}$ & $7.30250 * * *$ & $7.27685^{* * *}$ \\
\hline $\mathrm{RND}^{*} \mathrm{D}_{\mathrm{M}}$ & - & $-7.51505^{* * *}$ & $-5.34188^{* * *}$ & $-4.35150 * * *$ \\
\hline $\mathrm{RND} * \mathrm{D}_{\mathrm{H}}$ & $?$ & $-5.81784 * * *$ & $-2.32051 * * *$ & $1.10968^{*}$ \\
\hline $\mathrm{D}_{\mathrm{M}}$ & $?$ & 32.54458 & 139.50128 & 34.48061 \\
\hline $\mathrm{D}_{\mathrm{H}}$ & $?$ & 86.18603 & 151.26645 & $464.83371^{* *}$ \\
\hline \multicolumn{2}{|c|}{$\Sigma Y \mathrm{Y}$} & Included & Included & Included \\
\hline \multicolumn{2}{|c|}{$\Sigma I N D$} & Included & Included & Included \\
\hline \multicolumn{2}{|c|}{ F Value } & 738.47 & 730.49 & 763.46 \\
\hline \multicolumn{2}{|c|}{ Adj R-Sq } & 0.6834 & 0.6811 & 0.6904 \\
\hline \multicolumn{2}{|c|}{ Number of sample } & 7,649 & 7,649 & 7,649 \\
\hline
\end{tabular}

1) Variable definitions: refer to Table 2

2) Piecewise linear regression model: $M V_{i, t}=a_{0}+a_{1} B V_{i, t-1}+a_{2} N I_{i, t}+a_{3} R N D_{i, t}+a_{4} R N D_{i, t} * D_{1}+$ $a_{5} R N D_{i, t} * D_{2}+D_{1}+D_{2}+\varepsilon_{i, t}$

3) $D_{1}$ : dummy variable, if sales are bigger than first breakpoint $D=1$ and smaller than second breakpoint, otherwise $\mathrm{D}=0$

4) $\mathrm{D}_{2}$ : dummy variable, if sales are bigger than second breakpoint $\mathrm{D}=1$, otherwise $\mathrm{D}=0$

5) $* p<0.1, * * p<0.05, * * * p<0.01$

Similarly to the results shown in tables 4,5 , and 6 , technology innovation is nonlinearly related (as in an inverted U-shape) to firm value as it relates to sales volume.

4.2.6 Piecewise Linear Regression According to Debt Ratio

This paper runs a piecewise linear regressions to test the nonlinear value relevance of R\&D according to debt ratio in small and medium Korean companies. For this test, this paper splits the sample firms into two or three intervals according to their debt ratios by one or two breakpoints. Two intervals are divided by one breakpoint, producing the First Quartile (25\%), the Second Quartile (50\%), and the Third Quartile (75\%), and three intervals are divided by two breakpoints, producing ranges between the First Quartile $(25 \%)$ and the Second $(50 \%)$, between the Second (50\%) and the Third (75\%), and between the Second (50\%) and the Ninth Deciles (90\%).

\subsubsection{Piecewise Linear Regression According to Debt Ratio: On Breakpoint}

Table 9 presents the piecewise linear regressions used to test the nonlinear value relevance of R\&D by dividing the sample firms into two intervals for the period covering 2001 to 2011 . This part sets two intervals by one point of inflection, producing the First Quartile (25\%), Second Quartile (50\%), and Third Quartile (75\%) in models 1,2 , and 3 .

In Table 9, the coefficients of RND, RND*D, and D stand for the intercepts and slopes for the lower and higher debt ratio intervals. Table 9 indicates that the slopes of $R \& D$ in the lower and higher intervals differ at the $1 \%$ level of significance in every model. In model 1, the slopes of RND are 9.69126 in the lower interval and 4.2243 $(9.69126+(-) 6.25496)$ in the higher interval. In model 2, the slopes of RND are 7.12565 in the lower interval and 
$3.61469(7.12565+(-) 4.79343)$ in the higher interval. In model 3, the slopes of RND are 5.20441 in the lower interval and $4.03976(5.20441+(-) 3.31434)$ in the higher interval.

The coefficients of RND*D displays negative estimates at the $1 \%$ level of significance in every model. This indicates that $R \& D$ is nonlinearly related to firm value as it relates to debt ratio and thus that the value relevance of $R \& D$ investment decreases as the increase of debt ratio.

Table 9. Piecewise linear regression according to the size of the debt ratio: one breakpoint

\begin{tabular}{|c|c|c|c|c|}
\hline \multicolumn{2}{|c|}{ Variables } & \multicolumn{3}{|c|}{1 Break point } \\
\hline \multicolumn{2}{|c|}{ \& Expected Sign } & Model 1 & Model 2 & Model 3 \\
\hline Variables & Expected Sign & 1st Quartile (25\%) & $2^{\text {nd }}$ Quartile (50\%) & $3^{\text {rd }}$ Quartile (75\%) \\
\hline Intercept & $?$ & $3007.74861^{* * *}$ & $2790.38174 * * *$ & $2838.40633^{* * *}$ \\
\hline BV & + & $0.34643 * * *$ & $0.34448 * * *$ & $0.34904 * * *$ \\
\hline NI & + & $1.63969 * * *$ & $1.66270 * * *$ & $1.62523 * * *$ \\
\hline RND & + & $9.69126^{* * *}$ & $7.12565 * * *$ & $5.20441 * * *$ \\
\hline $\mathrm{RND} * \mathrm{D}$ & - & $-6.25496 * * *$ & $-4.79343 * * *$ & $-3.31434 * * *$ \\
\hline $\mathrm{D}$ & $?$ & $-354.99085^{* * *}$ & 29.19120 & $194.83863^{*}$ \\
\hline \multicolumn{2}{|c|}{$\Sigma \mathrm{YD}$} & Included & Included & Included \\
\hline \multicolumn{2}{|c|}{$\Sigma \mathrm{IND}$} & Included & Included & Included \\
\hline \multicolumn{2}{|c|}{ F Value } & 875.13 & 810.25 & 792.05 \\
\hline \multicolumn{2}{|c|}{ Adj R-Sq } & 0.6994 & 0.6828 & 0.6780 \\
\hline \multicolumn{2}{|c|}{ Number of sample } & 7,649 & 7,649 & 7,649 \\
\hline
\end{tabular}

1) Variable definitions: refer to Table 2

2) Piecewise linear regression model: $M V_{i, t}=a_{0}+a_{1} B V_{i, t-1}+a_{2} N I_{i, t}+a_{3} R N D_{i, t}+a_{4} R N D_{i, t} * D+D+\varepsilon_{i, t}$

3) $\mathrm{D}$ : dummy variable, if debt ratio is bigger than breakpoint $\mathrm{D}=1$, otherwise $\mathrm{D}=0$

4) $* p<0.1, * * p<0.05, * * * p<0.01$

4.2.6.2 Piecewise Linear Regression According to the Size of Debt Ratio: Two Breakpoints

This study runs a piecewise linear regression by setting three intervals by two points of inflection according to debt ratio. In Table 10, dummy variables $\mathrm{D}_{\mathrm{M}}$ and $\mathrm{D}_{\mathrm{H}}$, represent the inflection points of the middle and high intervals respectively according to debt ratio.

As Table 10 indicates, the slopes of the lower, middle, and higher debt ratio intervals differ significantly at the 1\% level of significance in every model. The result of model 1 shows that the slopes of RND are 9.68466 in the lower interval, $3.97761(9.68466+(-) 5.70705)$ in the middle interval, and $1.88406(9.68466+(-) 7.80060)$ in the higher interval. In model 2, the slopes of RND are 7.12326 in the lower interval, $2.74251(7.12326+(-) 4.38075)$ in the middle interval, and $1.9069(7.12326+(-) 5.21636)$ in the higher interval. In model 3, the slopes of RND are 6.87924 in the lower interval, $2.7134(6.87924+(-) 4.16584)$ in the middle interval, and 1.38875 $(6.87924+(-) 5.49049)$ in the higher interval. These results show that R\&D is nonlinearly related to a firm's value according to the size of the debt ratio.

As with the results in tables 4, 5, 6, 7, and 8, technology innovation is nonlinearly related to firm value (in the form of an inverted $U$-shape) as it relates to the size of the debt ratio.

\subsubsection{Piecewise Linear Regression According to R\&D Intensity}

This paper runs a piecewise linear regression by dividing the sample data into two or three intervals according to $R \& D$ intensity to test the nonlinear value relevance of the R\&D in small and medium Korean companies. This paper splits the sample into two intervals by one point of inflection, producing the First Quartile (25\%), Second Quartile (50\%), and Third Quartile (75\%) and then further divides the sample into three intervals by two points 
of inflection, producing ranges between the First Quartile (25\%) and the Second (50\%), between the Second $(50 \%)$ and the Third (75\%), and between the Second (50\%) and the Ninth Deciles $(90 \%)$.

Table 10. Piecewise linear regression according to the size of the debt ratio: two breakpoints

\begin{tabular}{|c|c|c|c|c|}
\hline \multirow{2}{*}{\multicolumn{2}{|c|}{$\begin{array}{c}\text { Variables } \\
\text { \& Expected Sign }\end{array}$}} & \multicolumn{3}{|c|}{2 Break points } \\
\hline & & Model 1 & Model 2 & Model 3 \\
\hline \multirow{2}{*}{ Variables } & \multirow{2}{*}{$\begin{array}{l}\text { Expected } \\
\text { Sign }\end{array}$} & $\begin{array}{l}\text { 1st break point: 1st Quartile } \\
(25 \%)\end{array}$ & $\begin{array}{c}\text { 1st break point: } 2^{\text {nd }} \text { Quartile } \\
(50 \%)\end{array}$ & $\begin{array}{c}\text { 1st break point: } 2^{\text {nd }} \text { Quartile } \\
(50 \%)\end{array}$ \\
\hline & & $\begin{array}{c}2^{\text {nd }} \text { break point: } 3^{\text {rd }} \text { Quartile } \\
(75 \%)\end{array}$ & $\begin{array}{c}2^{\text {nd }} \text { break point: } 3^{\text {rd }} \text { Quartile } \\
(75 \%)\end{array}$ & $\begin{array}{c}2^{\text {nd }} \text { break point: } 9^{\text {th }} \text { Deciles } \\
(90 \%)\end{array}$ \\
\hline Intercept & $?$ & $2989.58958 * * *$ & $2776.67092 * * *$ & $2845.85672 * * *$ \\
\hline $\mathrm{BV}$ & + & $0.34695 * * *$ & $0.34593 * * *$ & $0.34440 * * *$ \\
\hline NI & + & $1.64466^{* * *}$ & $1.65644 * * *$ & $1.66731 * * *$ \\
\hline RND & + & $9.68466^{* * *}$ & $7.12326^{* * *}$ & $6.87924 * * *$ \\
\hline $\mathrm{RND} * \mathrm{D}_{\mathrm{M}}$ & - & $-5.70705^{* * *}$ & $-4.38075^{* * *}$ & $-4.16584 * * *$ \\
\hline $\mathrm{RND} * \mathrm{D}_{\mathrm{H}}$ & $?$ & $-7.80060 * * *$ & $-5.21636^{* * *}$ & $-5.49049 * * *$ \\
\hline $\mathrm{D}_{\mathrm{M}}$ & $?$ & $-491.92196 * * *$ & -153.05951 & -177.97348 \\
\hline $\mathrm{D}_{\mathrm{H}}$ & $?$ & -40.88066 & $217.58782 *$ & $695.97019 * * *$ \\
\hline \multicolumn{2}{|c|}{$\Sigma \mathrm{YD}$} & Included & Included & Included \\
\hline \multicolumn{2}{|c|}{$\Sigma I N D$} & Included & Included & Included \\
\hline \multicolumn{2}{|c|}{ F Value } & 795.36 & 735.86 & 733.35 \\
\hline \multicolumn{2}{|c|}{ Adj R-Sq } & 0.6993 & 0.6826 & 0.6818 \\
\hline \multicolumn{2}{|c|}{ Number of sample } & 7,649 & 7,649 & 7,649 \\
\hline
\end{tabular}

1) Variable definitions: Refer to Table 2

2) Piecewise linear regression model: $M V_{i, t}=a_{0}+a_{1} B V_{i, t-1}+a_{2} N I_{i, t}+a_{3} R N D_{i, t}+a_{4} R N D_{i, t} * D_{1}+$ $a_{5} R N D_{i, t} * D_{2}+D_{1}+D_{2}+\varepsilon_{i, t}$

3) $D_{1}$ : dummy variable, if debt ratio is bigger than the first break point $D=1$ and smaller than the second breakpoint, otherwise $\mathrm{D}=0$

4) $\mathrm{D}_{2}$ : dummy variable, if debt ratio is bigger than the second breakpoint $\mathrm{D}=1$, otherwise $\mathrm{D}=0$

5) $* p<0.1, * * p<0.05, * * * p<0.01$

\subsubsection{Piecewise Linear Regression According to R\&D Intensity: One Breakpoint}

Table 11 presents the piecewise linear regressions used to test the nonlinear value relevance of R\&D by dividing the sample companies into two intervals according to $R \& D$ intensity. This part sets two intervals by one point of inflection, producing the First Quartile (25\%), Second Quartile (50\%), and Third Quartile (75\%) in every model.

In Table 11, the coefficients of RND, RND*D, and D stand for the intercepts and slopes for the lower and higher $R \& D$ intensity intervals. Table 11 shows that the value relevance of $R \& D$ in the lower and higher intervals differs at the $1 \%$ level of significance in every model.

Model 1 shows that the slopes of RND are 61.05342 in the lower interval and $4.19153(61.05342+(-) 56.86189)$ in the higher interval. Model 2 shows that the slopes of RND are 6.18258 in the lower interval and 3.89469 $(6.18258+(-) 2.28789)$ in the higher interval. In model 3, the slopes of RND are 2.98069 in the lower interval and $4.38538(2.98069+1.40469)$ in the higher interval. The coefficients of RND*D display negative estimates at the $1 \%$ level of significance in models 1 and 2 but positive estimates at the $1 \%$ level of significance in model 3 . This result indicates that $R \& D$ is nonlinearly related to firm value as it relates to $R \& D$ intensity and suggests that $R \& D$ has less value relevance as R\&D intensity increases in models 1 and 2 but more value relevance as R\&D intensity increases in model 3 . 
Table 11. Piecewise linear regression according to R\&D intensity: one breakpoint

\begin{tabular}{|c|c|c|c|c|}
\hline \multirow{2}{*}{\multicolumn{2}{|c|}{ Variables \& Expected Sign }} & \multicolumn{3}{|c|}{1 Break point } \\
\hline & & \multirow{2}{*}{$\frac{\text { Model } 1}{\text { 1st Quartile (25\%) }}$} & \multirow{2}{*}{$\frac{\text { Model } 2}{2^{\text {nd }} \text { Quartile }(50 \%)}$} & \multirow{2}{*}{$\frac{\text { Model } 3}{3^{\text {rd }} \text { Quartile }(75 \%)}$} \\
\hline Variables & Expected Sign & & & \\
\hline Intercept & $?$ & $2527.23294 * * *$ & $2687.26829 * * *$ & $2819.89049 * * *$ \\
\hline BV & + & $0.35014 * * *$ & $0.35311 * * *$ & $0.35412 * * *$ \\
\hline $\mathrm{NI}$ & + & $1.59832 * * *$ & $1.63990 * * *$ & $1.66474 * * *$ \\
\hline RND & + & $61.05342 * * *$ & $6.18258 * * *$ & $2.98069 * * *$ \\
\hline $\mathrm{RND} * \mathrm{D}$ & - & $-56.86189 * * *$ & $-2.28789 * *$ & $1.40469 * * *$ \\
\hline D & $?$ & $617.62307 * * *$ & $648.71858 * * *$ & $488.11884^{* * *}$ \\
\hline \multicolumn{2}{|c|}{$\Sigma Y D$} & Included & Included & Included \\
\hline \multicolumn{2}{|c|}{$\Sigma I N D$} & Included & Included & Included \\
\hline \multicolumn{2}{|c|}{ F Value } & 797.78 & 783.23 & 785.18 \\
\hline \multicolumn{2}{|c|}{ Adj R-Sq } & 0.6797 & 0.6755 & 0.6760 \\
\hline \multicolumn{2}{|c|}{ Number of sample } & 7,649 & 7,649 & 7,649 \\
\hline
\end{tabular}

1) Variable definitions: refer to Table 2

2) Piecewise linear regression model: $M V_{i, t}=a_{0}+a_{1} B V_{i, t-1}+a_{2} N I_{i, t}+a_{3} R N D_{i, t}+a_{4} R N D_{i, t} * D+D+\varepsilon_{i, t}$

3) $\mathrm{D}$ : dummy variable, if $\mathrm{R} \& \mathrm{D}$ intensity bigger than breakpoint $\mathrm{D}=1$, otherwise $\mathrm{D}=0$

4) $* p<0.1, * * p<0.05, * * * p<0.01$

4.2.7.2 Piecewise Linear Regression According to R\&D Intensity: Two Breakpoints

Table 12. Piecewise linear regression according to R\&D intensity: two breakpoints

\begin{tabular}{|c|c|c|c|c|}
\hline \multirow{2}{*}{\multicolumn{2}{|c|}{$\begin{array}{c}\text { Variables } \\
\& \text { Expected Sign }\end{array}$}} & \multicolumn{3}{|c|}{2 Break points } \\
\hline & & Model 1 & Model 2 & Model 3 \\
\hline \multirow[b]{2}{*}{ Variables } & \multirow{2}{*}{$\begin{array}{l}\text { Expected } \\
\text { Sign }\end{array}$} & $\begin{array}{c}\text { 1st break point: 1st Quartile } \\
(25 \%)\end{array}$ & $\begin{array}{c}\text { 1st break point: } 2^{\text {nd }} \text { Quartile } \\
(50 \%)\end{array}$ & $\begin{array}{c}\text { 1st break point: } 2^{\text {nd }} \text { Quartile } \\
(50 \%)\end{array}$ \\
\hline & & $\begin{array}{c}2^{\text {nd }} \text { break point: } 3^{\text {rd }} \text { Quartile } \\
(75 \%)\end{array}$ & $\begin{array}{c}2^{\text {nd }} \text { break point: } 3^{\text {rd }} \text { Quartile } \\
(75 \%)\end{array}$ & $\begin{array}{c}2^{\text {nd }} \text { break point: } 9^{\text {th }} \text { Deciles } \\
(90 \%)\end{array}$ \\
\hline Intercept & $?$ & $2458.90621 * * *$ & $2647.68803 * * *$ & $2657.27252 * * *$ \\
\hline BV & + & $0.35277 * * *$ & $0.35239 * * *$ & $0.35316^{* * *}$ \\
\hline NI & + & $1.63225^{* * *}$ & $1.67840 * * *$ & $1.65853^{* * *}$ \\
\hline RND & + & $57.73130^{* * *}$ & $5.96384 * * *$ & $6.06853^{* * *}$ \\
\hline $\mathrm{RND}^{*} \mathrm{D}_{\mathrm{M}}$ & - & $-55.50034 * * *$ & $-4.43295^{* * *}$ & $-2.35219 * *$ \\
\hline $\mathrm{RND} * \mathrm{D}_{\mathrm{H}}$ & $?$ & $-53.31648 * * *$ & -1.52358 & $-2.30793 * *$ \\
\hline $\mathrm{D}_{\mathrm{M}}$ & $?$ & $613.05604 * * *$ & 728.13412 & $614.08919 * * *$ \\
\hline $\mathrm{D}_{\mathrm{H}}$ & $?$ & $909.42825^{* * *}$ & 728.98789 & $991.76101 * * *$ \\
\hline \multicolumn{2}{|c|}{$\Sigma \mathrm{YD}$} & Included & Included & Included \\
\hline \multicolumn{2}{|c|}{$\Sigma I N D$} & Included & Included & Included \\
\hline \multicolumn{2}{|c|}{ F-Value } & 725.98 & 718.81 & 719.71 \\
\hline \multicolumn{2}{|c|}{ Adj R-Sq } & 0.6798 & 0.6775 & 0.6778 \\
\hline \multicolumn{2}{|c|}{ Number of sample } & 7,649 & 7,649 & 7,649 \\
\hline
\end{tabular}

1) Variable definitions: refer to Table 2 
2) Piecewise linear regression model: $M V_{i, t}=a_{0}+a_{1} B V_{i, t-1}+a_{2} N I_{i, t}+a_{3} R N D_{i, t}+a_{4} R N D_{i, t} * D_{1}+$ $a_{5} R N D_{i, t} * D_{2}+D_{1}+D_{2}+\varepsilon_{i, t}$

3) $D_{1}$ : dummy variable, if $R \& D$ intensity bigger than the first breakpoint $D=1$ and smaller than the second breakpoint, otherwise $\mathrm{D}=0$

4) $\mathrm{D}_{2}$ : dummy variable, if R\&D intensity bigger than the second breakpoint $\mathrm{D}=1$, otherwise $\mathrm{D}=0$

5) $* p<0.1, * * p<0.05, * * * p<0.01$

This section runs a piecewise linear regression by dividing the sample companies into three intervals according to R\&D intensity. $D_{M}$ and $D_{H}$ are dummy variables indicating the inflection points of the middle and high intervals according to R\&D intensity.

Table 12 shows that the slopes for R\&D in the low, middle, and high R\&D intensity intervals differ significantly at the $1 \%$ level of significance in models 1 and 3 but that the coefficient of $R N D * D_{\mathrm{H}}$ is not significant in model 3.

Model 1 shows that the slopes of RND are 57.73130 in the lower interval, $2.23096(57.73130+(-) 55.50034)$ in the middle interval, and $4.41482(57.73130+(-) 53.31648)$ in the higher interval. Model 2 shows that the slopes of RND are 5.96384 in the lower interval, $1.53089(5.96384+(-) 4.43295)$ in the middle interval, and 4.44026 $(5.96384+(-) 1.52358)$ in the higher interval. In model 3, the slopes of RND are 6.06853 in the lower interval, $3.71634(6.06853+(-) 2.35219)$ in the middle interval, and $3.7606(6.06853+(-) 2.30793)$ in the higher interval. These results indicate that $R \& D$ is nonlinearly related to firm value as it relates to $R \& D$ intensity.

The test results shown in tables 11 and 12 follow the pattern seen in the previous empirical results (in tables 4, 5, $6,7,8,9$, and 10), indicating that technology innovation has a nonlinear (inverted U-shaped) relationship with firm value as it relates to $R \& D$ intensity.

\section{Conclusions}

This study examines the nonlinear value relevance of $R \& D$ as a proxy for technology innovation in small and medium Korean companies over the period from 2001 to 2011. This study uses the Ohson (1995) model, adopts the empirical method in Morck et al. (1988), and runs piecewise linear regressions by dividing the sample companies into two or three categories according to asset size, sales, debt ratio, and R\&D intensity.

The empirical results suggest that $R \& D$ investment is nonlinearly related to firm value according to asset size, sales, debt ratio, and R\&D intensity for small and medium Korean companies. Details are provided below.

Hypothesis 1, that technology innovation has a nonlinear relationship with the market value of equity according to firm size in small and medium Korean companies, is significantly supported at the $1 \%$ level. This paper uses the size of assets and sales for the proxy measure of firm size. These empirical results are in line with prior research such as Schumpeter (1942), Scherer (1965), Chauvin and Hirschey (1993), Jung and Lee (1996), and Kim and Marschke (2004), who indicate that R\&D is nonlinearly associated with firm size. Our results demonstrate that technology innovation is nonlinearly related (with an inverted U-shape) to firm value as it relates to firm size.

Hypothesis 2, that technology innovation has a nonlinear relationship with the market value of equity according to debt ratio in small and medium Korean companies, is also supported at the $1 \%$ level of significance. This result differs from that of prior research such as Jensen (1986), James (1987), and Zantout (1997), who report that R\&D most benefits firms with high debt because of the monitoring role of creditors. As with hypothesis 1 , the result of hypothesis 2 reveals that technology innovation is nonlinearly related to firm value (in an inverted U-shape) as it relates to debt ratio.

Hypothesis 3, that technology innovation has a nonlinear relationship with the market value of equity according to R\&D intensity in small and medium Korean companies, is significantly supported at the $1 \%$ level, a result similar to that of prior studies, such as Lee (2005), that indicate that the market concentration ratio has a negative or inverted U-shaped relationship with R\&D intensity. This paper also shows that technology innovation is nonlinearly related to firm value (in an inverted U-shape) according to R\&D intensity. The test result of hypothesis 3 suggests that a high level of market concentration such as that produced by R\&D intensity decreases the power of technology innovation as a driver in small and medium Korean companies, thus indicating that, although $R \& D$ is a core value-relevant factor in small and medium companies, excessive $R \& D$ investment may deplete a firm's value. This result provides new insight into technology innovation's value relevance while also indicating that a nonlinear valuation model is needed for the assessment of small and medium Korean companies. 


\section{References}

Acs, Z. J., \& Audretsch, D. B. (1989). Job Creation and Firm Size in the US and West Germany. International Small Business Journal, 7(4), 9-22. http://dx.doi.org/10.1177/026624268900700401

Aghion, P., Angeletos, G., Banerjee, A., \& Manova, K. (2005). Volatility and Growth: Credit Constraints and Productivity - Enhancing Investment. NBER working Paper No. 11349.

Ahn, H. B., \& Kwon, G. J. (2006). An Analysis on Firm's Value based the Innovation of R\&D. Korean Accounting Review, 31(3), 27-61. [Printed in Korean].

Bublitz, B., \& Ettredge, M. (1989). The Information in Discretionary Outlays: Advertising and Research and Development. Accounting Review, 64, 108-124.

Chan, H., Martin, J., \& Kensinger, J. (1990). Corporate Research and Development Expenditure and Share Value. Journal of Financial Economics, 26(2), 255-276. http://dx.doi.org/10.1016/0304-405X(90)90005-K

Chauvin, K. W., \& Hirschey, M. (1993). Advertising, R\&D Expenditures and the Market Value of the Firm. Financial Management, 128-140. http://dx.doi.org/10.2307/3665583

Cho, S. P., \& Jung, J. Y. (2001). Multi-period Effect of R\&D Expenditures on Accounting Income. Korean Management Review, 289-310. [Printed in Korean]

Chung, H. Y., \& Cho, S. I. (2004). Value-Relevance of Accounting Information on Intangibles. Korean Accounting Review, 29(3), 1-31. [Printed in Korean].

Cohen, W. M., \& Klepper, S. (1994). A Reprise of Size and R\&D. Carnegie Mellon University. mimeo.

Comanor, W. S., \& Scherer, F. M. (1969). Patent Statistics as a Measure of Technical Change. Journal of Political Economy, 77(3), 392-398. http://dx.doi.org/10.1086/259522

Coombs, J., \& Bierly, P. (2006). Measuring technological capability and performance. R\&D Management, 36(4), 421-438. http://dx.doi.org/10.1111/j.1467-9310.2006.00444.x

Griliches, Z., \& Mairesse, J. (1984). Productivity and R\&D at Firm Level. R\&D, Patent and Productivity (pp. 339-374). Chicago: Univ. of Chicag Press.

Hall, B. H. (1999). Innovation and Market Value. NBER Working Paper No. 6984. Cambridge, MA

Hauseman, J. A., Hall, B. H., \& Griliches, Z. (1984). Econometric Models for Count Data with an Application to the Patents R and D Relationship. Econometrica, 52, 909-938. http://dx.doi.org/10.2307/1911191

Hirschey, M. (1982). Intangible Capital Aspects of Advertising and R\&D Expenditures. Journal of Accounting Research, 30, 375-390.

Hirschey, M., \& Weygandt, J. (1985). Amortization Policy for Advertising and Research and Development Expenditures. Journal of Accounting Research, 23(Spring), 326-335. http://dx.doi.org/10.2307/2490921

Ho, Y. K., Tjahjapranata, M., \& Yap, C. M. (2006). Size, Leverage, Concentration, and R\&D Investment in Generating Growth Opportunities. Journal of Business, 79, 851-876. http://dx.doi.org/10.1086/499140

James, C. (1987). Some Evidence on the Uniqueness of Bank Loans. Journal of Financial Economics, 19(2), 217-235. http://dx.doi.org/10.1016/0304-405X(87)90003-1

Jensen, M. (1986). Agency Costs of Free Cash Flow, Corporate Finance, and Takeovers. American Economic Review, 76(2), 323-329.

Kamien, M., \& Schwartz, N. (1982). Market Structure and Innovation (Chap. 2, pp. 22-48). Cambridge: Cambridge University Press.

Kang, M. -H., (1994). Concentration of Economic Power and Technology Innovation. The Korean Economic Review, 41(3), 3-25. [Printed in Korean].

Kim, J., \& Marschke, G. (2004). Accounting for the recent surge in U.S. patenting: International Knowledge Flows 347 Changes in R\&D expenditures, patent yields, and the high tech sector. Economics of Innovation and New Technology, 13(6), 543-558. http://dx.doi.org/10.1080/1043859032000124693

Korea Institute of Science \& Technology Evaluation and Planning (KISTEP). (2011). Survey of Research and Development in Korea -Key Figures of Korea R\&D Activities. 
Korea Institute of Science \& Technology Evaluation and Planning (KISTEP). (2012). The Direction for the R\&D Investment and Aid of Korean Small and Medium Companies. KISTEP Issue paper 2012-03 [Printed in Korean].

Kothari, S. P., Laguerre, T. E., \& Leone, A. J. (2002). Capitalization Versus Expensing: Evidence On The Uncertainty Of Future Earnings From Capital Expenditures Versus R\&D Outlays. Review of Accounting Studies, 7, 355-382. http://dx.doi.org/10.1023/A:1020764227390

Kwon G. -J., (2009a). An Empirical Analysis on the Capitalization of Ordinary R\&D Expenditure. Journal of the Korean Data Analysis Society, 10(6), 3333-3346. [Printed in Korean].

Kwon G. -J., (2009b). The Value Relevance of Intangible Expenditures. Journal of the Korean Data Analysis Society, 11(3), 1593-1608. [Printed in Korean].

Kwon G. -J., (2010). The Relevance Between R\&D Investment and Internal Cash Flows: Focuses on Changes of Sale, Debt Ratio, and Growth Opportunity. Journal of the Korean Data Analysis Society, 12(3), 1663-1676. [Printed in Korean].

Kwon, G. -J. (2008). The Impact of Training Expenditure on Firm's Productivity. Journal of the Korean Data Analysis Society, 10(4), 2221-2232. [Printed in Korean].

Lee, C. Y. (2005). A New Perspective on Industry R\&D and Market Structure. Journal of Industrial Economics, 53(1), 101-121. http://dx.doi.org/10.1111/j.0022-1821.2005.00247.x

Lee, P. M., \& O'Neill, H. M. (2003). Ownership Structures and R\&D Investments of U.S. and Japanese Firms: Agency and Stewardship Perspectives. The Academy of Management Journal, 46(2), 212-225. http://dx.doi.org/10.2307/30040615

Lev, B., \& Sougiannis, T. (1996). The capitalization, amortization, and value-relevance of R\&D. Journal of Accounting and Economics, 21, 107-138. http://dx.doi.org/10.1016/0165-4101(95)00410-6

Levin, R. C. (1978). Technical Change, Barriers to Entry, and Market Structure. Economica, 45, 347-361. http://dx.doi.org/10.2307/2553450

Mahmood, O. P., \& Lee, C. -Y. (2004). Business Groups: Entry Earrier-Innovation Debate Revisited. Journal of Economic Behavior and Organization, 54(4), 513-531. http://dx.doi.org/10.1016/j.jebo.2002.12.003

McConnell, J., \& Servaes, H. (1995). Equity Ownership and the Two Faces of Debt. Journal of Financial Economics, 39(1), 131-157.

Morck, R., Shleifer, A., \& Vishny, R. W. (1988). Management Ownership and Market Valuation. Journal of Financial Economics, 20, 293-315.

Ohlson, J. (1995). Earnings, Book Values, and Dividends in Equity Valuation. Contemporary Accounting Research, 11(Spring), 661-687.

Park, B. J. (2010). R\&D intensity and Market Structure in Korean Manufacturing Industries. Journal of Economics Studies, 28(4), 75-98.

Rosenberg, J. B. (1976). Research and Market Share: A Reappraisal The Schumpeter Hypothesis. Journal of Industrial Economics, 25(2), 101-112. http://dx.doi.org/10.2307/2098260

Scherer, F. M. (1965). Firm Size, Market Structure, Opportunity, and the Output of Patented Inventions. American Economic Review, 55, 1097-1125.

Scherer, F. M. (1967). Market Structure and the Employment of Scientists and Engineers. American Economic Review, 57, 524-531.

Schumpeter, J. (1947). The Creative Response in Economic History. Journal of Economic History, 7, 149-159. http://dx.doi.org/10.1017/S0022050700054279

Schumpeter, J. (1942). Capitalism, Socialism and Democracy. New York, Wiley.

Shin, T. -Y., (1999). Firm Size and Innovation: A Probit Analysis. Journal of Korea Technology Innovation Society, 2(2), 169-186. [Printed in Korean].

Sougiannis, T. (1994). The Accounting Valuation of Corporate R\&D. The Accounting Review, 69, 44-68.

Vossen, R. W. (1999). Market Power, Industrial Concentration and Innovative Activity. Review of Industrial Organization, 15, 367-378. http://dx.doi.org/10.1023/A:1007727815408

Wolf, M. F. (2007). Forget R\&D Spending-Think Innovation. Research-Technology Management, 50, 7-9. 
Yoon, C. H., \& Kwon, J. E. (2002). An Empirical Study on the Schumpeterian Hypothesis in IT Industries of Korea. International Telecommunications Policy Review, 9(2), 219-245.

Zantout, Z. (1997). A Test of the Debt-Monitoring Hypothesis: The Case of Corporate R\&D Expenditures. Financial Review, 32(1), 21-48. http://dx.doi.org/10.1111/j.1540-6288.1997.tb00413.x

\section{Copyrights}

Copyright for this article is retained by the author(s), with first publication rights granted to the journal.

This is an open-access article distributed under the terms and conditions of the Creative Commons Attribution license (http://creativecommons.org/licenses/by/3.0/). 